\title{
Umberto Eco's semiotic threshold
}

\author{
Winfried Nöth \\ University of Kassel, \\ Georg-Forster-Str. 3, D-34109 Kassel, Germany \\ e-mail: noeth@uni-kassel.de
}

\begin{abstract}
The "semiotic threshold" is U. Eco's metaphor of the borderline between the world of semiosis and the nonsemiotic world and hence also between semiotics and its neighboring disciplines. The paper examines Eco's threshold in comparison to the views of semiosis and semiotics of C. S. Peirce. While Eco follows the structuralist tradition, postulating the conventionality of signs as the main criterion of semiosis, Peirce has a much broader concept of semiosis, which is not restricted to phenomena of culture but includes many processes in nature. Whereas Eco arrives at the conclusion that biological processes, such as the ones within the immune system, cannot be included in the program of semiotic research, Peirce's broader definition of semiosis has meanwhile become the foundation of semiotic studies in biology and medicine and hence in biosemiotics and medical semiotics.
\end{abstract}

\section{The boundaries of Eco's semiotic field}

Umberto Eco's semiotic threshold raises the question of the dividing line between the semiotic and the nonsemiotic world. In his Theory of Semiotics, Eco (1976: 9, 5) describes the area of contemporary research in semiotics as the "semiotic field" and defines the dividing lines between this field and the nonsemiotic world as "boundaries or thresholds". He distinguishes between transitory and immutable boundaries. There are two kinds of transitory boundaries, the political and the epistemological ones. The political boundaries are determined by the present limitations of the state of the art in current semiotic research and should therefore be crossed with the advance in semiotic 
theory. The epistemological boundaries represent the dividing line between semiotics as a theory and its object of study, and thus between theory and practice. The semiotician's crossing of this boundary should be one of critical intervention. Semiotic theory should affect semiotic practice. The result of such intervention should be a permanent remodeling of the semiotic landscape.

The boundaries to be investigated in the following are only the immutable ones. Eco (1976: 6) calls them the natural boundaries and defines them as "those beyond which a semiotic approach cannot go; for there is a nonsemiotic territory [...of] phenomena that cannot be taken as sign functions". Eco's semiotic field is separated from the nonsemiotic world by two kinds of natural boundaries, which he discusses as the lower and the upper threshold of semiotics.

The lower threshold represents the dividing line between the semiotic and the presemiotic world. To Eco (1976: 19-21), this threshold is the one that separates nature from culture. Since his theory is programmatically a semiotics of culture and of signs which presuppose social convention, processes in the domain of biological or physical nature are by definition excluded from semiotics. Thus, Eco comes to the conclusion that only signs based on codes and convention constitute the semiotic field, whereas stimuli, signals or physical information are below the semiotic threshold where "semiotic phenomena arise from something nonsemiotic" (Eco 1976: 21). The purpose of my paper will be to show that, from the perspective of general semiotics, Eco's lower semiotic threshold is too high and can be lowered to account for processes of semiosis in culture and in nature.

Eco's upper semiotic threshold is the dividing line between the semiotic and various other nonsemiotic perspectives of the world. Even within the domain of culture, which belongs most certainly to the semiotic field, we are not always exclusively confronted with sign phenomena, according to Eco (1976: 27). Objects of culture, for example, are not only signs. They are also physical objects constructed according to mechanical laws; they have an economic value and may have a social function. Possible nonsemiotic perspectives from which our cultural objects can then be considered are thus the physical, the mechanical, the economic, and the social perspectives, and these, according to Eco, are the perspectives from beyond the upper semiotic threshold. 


\section{Semiotics and the other sciences}

The semiotic perspectivism which Eco adopts in this context belongs to one of the most fruitful approaches to the question of the dividing line between semiotics and other sciences. It provides the appropriate argument against the reproach of semiotic imperialism (Eco 1976: 67), according to which semioticians dare to deal with too many phenomena, whose study should better be left to the specialists of other disciplines. Against this reproach, the perspectivist argues that semiotics does not aim at substituting its neighboring sciences, but rather at contributing a different perspective to the study phenomena that can be investigated from several points of view. The authority to which Eco (1976: 16) refers in this context is Morris (1938: 4), who argued that "semiotics, then, is not concerned with the study of a particular kind of object, but with ordinary objects in so far (and only in so far) as they participate in semiosis". A somewhat different perspectivism is also inherent in Hjelmslev's (1943: 108) view of semiotics as "a common point of view for a large number of disciplines from [...] literature [...] to mathematics". To Hjelmslev (1943: 77-78; 1954: 50), this world beyond semiotics is the amorphous and nebulous domain of content and expression purport. Language gives one kind of structure to this domain, namely a semiotic one, but Hjelmslev also recognizes that there are other sciences, such as physics or anthropology, which impose different kinds of structure to the same domain (cf. Nöth 1990: 68). While both Morris and Hjelmslev are thus semiotic perspectivists, the perspectives they take are quite opposed. Whereas Morris (1946: 80) wanted to establish a theory of signs "on a biological basis", Hjelmslev's basis of semiotics was the structure of language.

\section{Eco between biosemiotic expansionism and linguosemiotic reductionism}

Between these two extremes of semiotic expansionism and linguosemiotic reductionism, we find Eco as steering a middle course, pleading on the one hand for an extension, and on the other hand for a restriction of the semiotic field. In contrast to semioticians such as Buyssens (1943) and Prieto (1966), Eco extends the semiotic field by including both natural signs, even signs from a nonhuman source, and 
unintentional signs in the domain of semiotic study (Eco 1976: 15). Unlike Morris and Peirce, he restricts the semiotic field by insisting on social and cultural convention as a criterion of signs. Signals which are not based on convention, mere stimuli, and even the flow of information in machine-to-machine communication are not categorically excluded from Eco's semiotic scope, but they are classified as threshold phenomena which are of interest to semiotics only insofar as they participate in sign processes (Eco 1976: 41). ${ }^{1}$ In a similar way, we find the study of communication as a threshold phenomenon of Eco's semiotics. The definition which Eco (1976: 8) gives to the semiotics of communication in contrast to the semiotics of signification is exactly opposed to the way in which Buyssens (1943) and Prieto (1966) distinguish these two domains (cf. Nöth 1990: 172). Communication, according to Eco, is more generally the flow of signals, which may be signs or not, to a destination, which may be human or nonhuman, while signification presupposes signs and a human being as a destination. Thus, phenomena of signification always belong to the semiotic field, while communication may also occur below Eco's semiotic threshold.

\section{Sign, code, convention, and nature}

Since semiotics, according to Eco (1976: 7) "is concerned with everything that can be taken as a sign", Eco's definition of the sign can give us further insights into the delimitation of his semiotic field. Two of his criteria of a sign seem to establish a rather high semiotic threshold: conventionality or codedness, and the potential of being used to tell a lie. As far as the latter is concerned, Eco has recently abandoned his famous claim that "semiotics is in principle the discipline studying everything which can be used in order to lie" (Eco 1976: 7). In fact, the criterion was too strong. Lies are defined in opposition to truth, and it is well known that the true-false dichotomy is hardly relevant to the study of many sign phenomena, such as pictures or architecture (cf. Nöth 1997a). In Toronto, in 1995, Eco himself reduced this criterion to a weaker formula which states that "a sign is anything you can use to say something that is not necessarily the case", and with this

For a broader semiotic view of semiosis in machine-to-machine interaction see also Nöth 1997b. 
formulation, we are close to the structuralist view of the sign as being based on the principle of opposition (cf. Nöth 1994c).

The second criterion, conventionality, serves to differentiate between signs and nonsigns, such as mere stimuli. Eco (1976: 19) argues "since everything can be understood as a sign if and only if there exists a convention which allows it to stand for something else, and since some behavioral responses are not elicited by convention, stimuli cannot be regarded as signs". For the same reason, lack of conventionality, there are signals which are not signs because they are mere "units of transmission which can be computed quantitatively irrespective of their possible meaning" (Eco 1976: 20).

The criterion of conventionality is also the key to Eco's perspective of culture as a semiotic phenomenon (Eco 1976: 26-27): meanings are cultural units organized in oppositions and structures according to a code. Now, culture has traditionally been opposed to nature. How does Eco then account for natural signs in the framework of his cultural semiotics? How can the idea of conventionality be reconciled with the idea of natural signs, for example, symptoms or natural indices such as smoke indicating a fire or a wet spot indicating the fall of a raindrop? The semiotic bridge which Eco's approach offers between nature and culture consists in what I would like to call a radical culturalization of nature.

\section{Eco's culturalization of nature}

According to Eco's theory of semiotics, nature can be seen from a nonsemiotic and from a semiotic perspective. The nonsemiotic perspective is, for example, characteristic of everyday inferences (Eco 1976: 17). When we infer from smoke the presence of fire or from a wet spot the fall of a raindrop, or more generally, from a natural effect its natural cause, such inferences are not yet signs, according to Eco, but they can become signs if the association between cause and effect is the result of cultural learning and coding. The same phenomena can thus appear as inferential nonsigns and as cultural signs, depending on the absence or presence of conventionality and coding in the association between cause and effect. Eco exemplifies this transformation between the nonsemiotic and the semiotic from various domains of nature. At the level of physical nature, he argues that smoke, as long as it is perceived along with the fire which it causes is not a sign of it, 
"but smoke can be a sign-vehicle standing for a nonvisible fire, provided that a social rule has necessarily and usually associated smoke with fire" (Eco 1976: 17). The somewhat surprising distinction between these two cases, smoke seen in the presence or in the absence of the fire, has probably also to do with Eco's definition of the sign as something "which can be taken as significantly substituting for something else" (Eco 1976: 7). Eco probably believes that smoke seen in the presence of fire does not imply such a process of substitution. This view of a semiotic threshold existing between perceived and unperceived referent is related to Eco's argument that mirror images are no signs. Here, too, we have the simultaneity in the perception of the image in the mirror and its referent, the person in front of the mirror (Eco 1984: 202).

At the biological level, Eco argues that medical symptoms are only signs when they are recognized by the tradition of a medical doctrine:

The first doctor who discovered a sort of constant relationship between an array of red spots on the patient's face and a given disease (measles) made an inference: but insofar as this relationship has been made conventional and has been registered as such in medical treatises, a semiotic convention has been established. There is a sign every time a human group decides to use and to recognize something as the vehicle of something else (Eco 1976: 17).

At the level of human nonverbal communication, Eco (1973: 39) gives the example of spontaneous, noncodified expressions of emotions produced without any communicative intention to illustrate nonverbal phenomena below the semiotic threshold and argues that the same phenomena become codified and thus semiotic as soon as they exhibit cultural variation or are simulated or imitated in a histrionic context.

At the level of human artifacts, Eco's (1973: 43) example is Roland Barthes's raincoat, which is nonsemiotic insofar as it merely protects against rain, but semiotic insofar as it is a product of cultural fashion or as an indicator of the particular meteorological situation in which it is used. In sum, as soon as systems of convention intervene in the interpretation of natural phenomena and cultural artifacts, the semiotic threshold is crossed.

However, where does convention begin, and where does nature end? Eco gives no clear answer. Cognitive science, for example, has been emphasizing the dependence of cognition on the structure of the human mind and the impossibility of any direct access to the "real" nature of the phenomena. Many of our cognitions are universal and 
not culturally variable since they have developed according to universal laws of biological evolution (cf. Nöth 1994a). In the light of cognitive science, the dogma of cultural arbitrariness has more and more been questioned. Not even the favorite topic of cultural relativity, the semiotics of color names, has escaped from the universalist perspective of cognitive psychology, as Berlin and Kay (1969) have shown. Can the dogma of arbitrariness and conventionality thus still be accepted as the sole criterion of semioticity? In my view, Eco's semiotics suffers from overemphasizing this criterion. Conventionality is the basis of one mode of semiosis, but not the decisive criterion to distinguish between the nonsemiotic and the semiotic world. I would like to defend this argument with reference to Peirce's more general semiotic theory.

\section{Eco's vs. Peirce's semiotic threshold}

Peirce is one of Eco's crown witnesses for a desirable broadening of the semiotic field from its Saussurean logocentric restrictions (Eco 1976: 15-17). As far as the semiotic threshold is concerned, however, Eco's reading of Peirce is either incomplete or it results in a rejection of an approach to semiosis that Eco considers too broad. As we have seen above, Eco rejects Peirce's interpretation of inference as semiosis as being too broad from the premises of his own cultural semiotics (cf. Eco 1976: 17). Eco's interpretation of Peirce is incomplete, when he argues that Peirce's triad of sign, object, and interpretant "can also be applied to phenomena that do not have a human emitter, provided that they do have a human receiver, such being the case with meteorological symptoms or any other sort of index" (Eco 1976: 16).

In fact, the occurrence of signs and semiosis, according to Peirce, is not restricted to human receivers, but presupposes a much more general category which he calls mind. Mind, however, in Peirce's semiotics, does not only mean the human mind (cf. Santaella 1994). It includes the triadic interaction of any organism with its environment (cf. Nöth 1994b: 2-4). Peirce even goes so far as to extend the category of mind to nonbiological phenomena (CP 7.374). The action of mind in physical nature, according to Peirce's evolutionary philosophy, is the action of final causation, but let us focus only on the biosemiotic threshold in the following. 
The semiotic threshold which Peirce postulates is thus not the one between human and nonhuman minds, but between dyadic and triadic interactions. Semiosis begins when we cross the threshold from mere dyadic interactions between mechanical, chance, or "brute" (efficient) causes and their effects to triadic interactions mediated by a mind in the broadest sense. A semiotic triad is one in which a mind interprets (i.e., forms an interpretant of) a signifying stimulus in its environment, called representamen, relative to a goal (the object) which is distinct from this environmental stimulus, but not necessarily absent in the given situation. This interaction requires neither consciousness nor intentionality, but must be goal-directed. Metabolic "reactions" of an organism to environmental stimuli are goal-directed actions. Organisms select and hence evaluate, environmental energy or matter for the purpose of their own biological survival, while at the same time rejecting other environmental stimuli as unsuitable. In a similar way, the immune system exhibits goal-directed triadic interactions of a semiotic nature. The senders of immunological messages in the blood serum of an animal are the antigens, i.e., molecules of foreign substances such as bacteria or viruses. The receivers of these messages are the antibody molecules produced by the B-lymphocytes and the leukocytes, which are equipped with a multitude of receptors for the purpose of detecting the antigens (cf. Nöth 1994c: 49). Such processes exemplify semiotic thirdness above the lowest biosemiotic threshold (Nöth 1994b: 4).

On the premises of his cultural semiotics, Eco explicitly rejected the legitimacy of a place of such phenomena within his semiotic field. In his paper "On semiotics and immunology", which he contributed to the 1987 international conference on The Semiotics of Cellular Communication in the Immune System, Eco (1988) declared, to the disappointment of the assembled biosemioticians, that interpretations of immunological processes in terms of categories such as "communication", "sign perception", or "semiosis" are mere models or metaphors used in a domain other than the semiotic field. In this paper, he expresses the anthropocentric and cultural bias of his semiotics more clearly than in his Theory of Semiotics, when he states:

I can certainly say that if a dog wags its tail this means that it is happy or that if I see red spots on the face of a person this means the person has measles: but neither the dog nor the person follow the rules of a signsystem. If there is a sign system, it belongs to my competence and represents a semiotic rule I use to interpret events as if they were communicat- 
ing something to me. I guess that if an immunologist sees (if possible) a given lymphocyte doing so and so, he will be able to predict that something so and so will happen or had happened. But such a principle is common to all scientific research as well as to normal experience in our everyday life. [...] Nucleotides do not know that A 'means' U. They simply react by substituting A with $U$. We cannot say that nucleotides behave semiotically because we are unable to prove that they can refrain from interpreting or that they can choose alternative interpretations. (Eco 1988: $7-8)$.

In addition to anthropocentric and cultural bias, Eco's last argument testifies to another bias, which I would like to call his synchronic bias. Of course, the nucleotides are not equipped with the capacity for alternatives in the interpretations of their environment, but this is true only in a synchronic perspective. From the point of view of biological evolution, we certainly have had alternatives which began with mutations and the ensuing evolutionary preferences for the survival of the fittest.

Nevertheless, Eco's proposal for a semiotic threshold between mere stimuli and cultural signs seems to be related to Peirce's dividing line between dyadic and triadic process insofar as stimulus-response chains seem to be dyadically connected in an automatic sequence, whereas signs are culturally mediated. In fact, this is Eco's own argument. "A stimulus-response process", thus Eco (1988: 8) "is a dyadic one: A provokes B and must be present in order to elicit B (equally present). I understand that the requisite of the co-presence is a very ambiguous one. A stimulus-response is certainly a causal sequence."

Such a categorically asemiotic interpretation of stimulus-response sequences is not in accordance with Peirce's broad concept of semiosis. The response of an organism to a stimulus is determined by the disposition of the nervous system, which has evolved according to evolutionary laws. If it is "automatic", there is predictability, necessity, or generality, and these characteristics transform the seemingly dyadic interaction into a semiotic triad. At the same time, the stimulus-response example illustrates the essential difference between Eco's and Peirce's semiotic thresholds. In contrast to Eco, whose semiotics begins above the threshold of culture, convention, and codedness, Peirce's threshold begins much lower with phenomena determined by law, generality, habit, and final causation, excluding only phenomena determined by chance, mere efficient causation, and phenomena of unreflected firstness (cf. Santaella Braga 1994). 


\section{The symbolicity of Eco's signs}

A final essential respect in which Eco's semiotic field turns out to be much more restricted in comparison with the Peircean one brings us back to Eco's above discussed culturalization of nature and to the topic of the typology of signs. Eco's reluctant inclusion of natural indices in the semiotic field, only on the condition that such signs be sanctioned by a cultural code, actually means that he interprets such indices as symbols. At least, such conclusion suggests itself from a Peircean perspective. Signs established by culture and convention are primarily symbols, according to Peirce, but these are distinguished from icons and indices, which do not primarily depend on coding. The index is interpreted as a sign on the basis of a causality or spatiotemporal connection between the sign and its object, while the icon is interpreted as a sign because of qualities or features which it has in common with its object. This famous Peircean classification of the sign with respect to its object has to do with Peirce's three categories of firstness, secondness, and thirdness. While signs, by definition belong to the category of thirdness, they may exhibit in their object relation to various degrees features of firstness, secondness, and thirdness (cf. Nöth, Santaella 2000): in the icon, we are confronted with a foregrounding of the feature of firstness, in the index with secondness and in the symbol with thirdness. Eco's problems with the category of the iconic sign are well known, and cannot be discussed here in detail. Suffice it to say that it has also to do with the problem of reconciling the feature of firstness in the icon with the one of thirdness in the category of the sign. Our investigation of Eco's semiotic threshold has mainly been concerned with Eco's view of natural indices, which are signs because of their secondness. It may now have become apparent that Eco's culturalization of the natural sign is actually a result of his attempt to admit signs only on criteria of thirdness and not on criteria focusing on secondness.

\section{Conclusion}

Let me emphasize, in conclusion, that my Peircean perspective on Eco does not imply a criticism of Eco's semiotic theory for the limitations of its scope. Eco's cultural semiotics is certainly consistent in itself. 
The boundaries of the semiotic field which he establishes are a logical consequence of his semiotic premises. The fact that Peirce's field is broader is not an argument against Eco's theory of semiotics, but, on the other hand, semioticians are free to opt for either the broader Peircean or the narrower Ecoian field to make headway in the field of semiotic studies.

Although Eco never leaves any doubt about his conviction of the necessity of restricting the semiotic field from the premises of culture, he nevertheless once dares to risk a glance beyond the semiotic threshold established within his own system. At the end of his paper "On semiotics and immunology", Eco concludes with the following remark concerning the threshold between higher and lower biological processes with which we want to conclude our own paper on Eco's semiotic threshold: "As you probably understand," writes Eco (1988: 15), "such a question concerns the dramatic problem of the boundaries between Spirit and Matter, Culture and Nature. - Let me stop. I feel afraid."

\section{References}

Berlin, Brent and Kay, Paul 1969. Basic Color Terms. Berkeley: University of California Press.

Buyssens, Eric 1943. Les langages et le discours. Bruxelles: Office de la Publicité.

Eco, Umberto 1973. Segno. Milano: Isedi.

- 1976. A Theory of Semiotics. Bloomington: Indiana University Press.

- 1984. Semiotics and the Philosophy of Language. Bloomington: Indiana University Press.

- 1988. On semiotics and immunology. In: Sercarz, Eli E.; Celada, Franco; Michison, N. Avrion; Tada, Tomio (eds.), The Semiotics of Cellular Communication in the Immune System. Berlin: Springer, 3-15.

Hjelmslev, Louis 1943. Prolegomena to a Theory of Language. Madison: University of Wisconsin Press.

- 1954. La stratification du langage. In: Hjelmslev, Louis, Essais linguistiques. Copenhagen: Nordisk Sprog- og Kulturforlag, 37-68.

Morris, Charles W. 1938. Foundations of the Theory of Signs. Chicago: Chicago University Press.

- 1946. Signs, language, and behavior. In: Morris, Charles W., Writings on the General Theory of Signs. The Hague: Mouton, 73-398.

Nöth, Winfried 1990. Handbook of Semiotics. Bloomington: Indiana University Press. 
- 1994a. Semiotic foundations of the cognitive paradigm. Semiosis (BadenBaden) 73: 5-16.

- 1994b. Introduction. In: Nöth, Winfried (ed.), Origins of Semiosis: Sign Evolution in Nature and Culture. Berlin: Mouton de Gruyter, 1-12.

- 1994c. Oppositions at the roots of semiosis. In: Nöth, Winfried (ed.), Origins of Semiosis: Sign Evolution in Nature and Culture. Berlin: Mouton de Gruyter, 37-60.

- 1997a. Can Pictures Lie? In: Nöth, Winfried (ed.), Semiotics of the Media: State of the Art, Projects, and Perspectives. Berlin: Mouton de Gruyter, 133-146.

- 1997b. Representation in semiotics and in computer science. Semiotica 115: 203-213.

Nöth, Winfried and Santaella, Lucia 2000. Bild, Malerei und Photographie aus der Sicht der Peirceschen Semiotik. In: Wirth, Uwe (ed.), Die Welt als Zeichen und Hypothese. Frankfurt: Suhrkamp, 354-374.

Peirce, Charles Sanders 1931-1958. Collected Papers, vols. 1-6 (Hartshorne, Charles and Weiss, Paul, eds.), vols. 7-8 (Burks, Arthur W., ed.). Cambridge: Harvard University Press.

Prieto, Luis J. 1966. Messages et signaux. Paris: Presses Universitaires.

Santaella Braga, Lucia 1994. Peirce's broad concept of mind. $S$ : European Journal for Semiotic Studies 6: 399-411.

\section{“Семиотический порог” Умберто Эко}

“Семиотический порог" - это метафора У. Эко для обозначения границы между миром семиозиса и миром несемиотическим а также, следовательно, между семиотикой и смежными дисциплинами. В данной статье "порог" У. Эко рассматривается в сопоставлении со взглядами Ч. С. Пирса на семиозис и семиотику. Тогда как Эко, следуя структуралистской традиции, провозглашает основным критерием семиозиса конвенциональность знаков, пирсовский концепт семиозиса гораздо шире: он не сводится к феноменам культуры, но включает и многие процессы природы. Эко приходит к выводу, что биологические процессы, например, процессы в иммунной системе, не могут быть включены в программу семиотического исследования. Пирсовское широкое определение семиозиса стало, между тем, основой семиотических штудий в биологии и медицине и отсюда в биосемиотике и медицинской семиотике. 


\section{Umberto Eco "semiootiline lävi"}

"Semiootiline lävi" on Umberto Eco metafoor tähistamaks piiri semioosise ja mittesemiootilise maailma, järelikult ka semiootika ja temaga piirnevate distsipliinide vahel. Antud artiklis vaadeldakse U. Eco "läve" mõistet seoses Ch. S. Peirce'i vaadetega semioosisele ja semiootikale. Kui strukturalistlikust traditsioonist lähtuv Eco kuulutab semioosise põhikriteeriumiks märkide konventsionaalsuse, siis Peirce'i semioosise mõiste on tunduvalt laiahaardelisem: see ei haara mitte ainult kultuurifenomene, vaid sisaldab ka mitmeid loodusprotsesse. Eco tuleb järeldusele, et bioloogilisi protsesse (nt immunsüsteemis toimivaid) ei saa lülitada semiootilise uurimuse programmi. Samal ajal on Peirce'i tunduvalt laiem semioosisemääratlus aluseks semiootilistele käsitlustele bioloogias ja meditsiinis ning sealtkaudu ka biosemiootikas ja meditsiinisemiootikas. 